\title{
1 LINKING TOURISM INTO EMERGENCY \\ 2 MANAGEMENT STRUCTURES TO ENHANCE \\ 3 DisASTER RISK REDUCTION
}

4

5

6

Cite as: Becken, S. \& Hughey, K. (2013). Linking tourism into emergency management structures to enhance disaster risk reduction. Tourism Management, 36, 77-85.

\section{$\underline{\text { Abstract }}$}

Despite increased global interest in the impacts of natural disasters on tourism, little research has occurred into exploring how these are addressed at the destination level. Creating a link between tourism and disaster risk reduction and management is particularly important in places that rely heavily on tourism and, at the same time, are prone to natural hazards. New Zealand is a good example. Hence, in this paper we use the case study of the Northland region to explore how both tourism and disaster management stakeholders perceive the role of tourism in present and future disaster risk management activities. The overall finding is that tourism in Northland is currently poorly considered in existing disaster management planning, and recent natural disasters have identified a range of gaps and concerns within each of the Four Rs (Reduction, Readiness, Response and Recovery). Based on these insights, and building on the current Civil Defence structure, a template for linking tourism into disaster management is proposed and populated. A Tourism Action Plan, adopted by the Northland 'Tourism Cluster', provides a guideline for tourism specific initiatives that complement the existing Civil Defence plans, thus adding value to the formal disaster management efforts. Considering the lack of systematic disaster management in tourism reported in the literature, this research should also be of interest to other tourist destinations and their aspirations for long term sustainability.

\section{$\underline{\text { Keywords }}$}

Disaster Risk Reduction, Destination Management, Tourism Cluster, Civil Defence, Natural Hazards 


\section{Introduction}

32 Over the last decade a number of natural disasters severely affected tourist destinations. The most prominent examples include the 2004 Indian Ocean tsunami, Hurricane Katrina (USA)

34 (2005), the Samoan tsunami (2009), the Australian floods (2010/2011) and the Christchurch (New Zealand) earthquakes (2010/2011). In response to natural hazards, a range of organisations began to assist tourism in disaster management (e.g. WTO, 1998, APEC, 2006, Commonwealth of Australia, 2007; Tourism Queensland, 2007, 2009; Tourism Victoria, 2010; UNEP \& CAST, 2009), and build resilience in tourism-dependent communities (e.g. Larsen, Calgaro \& Thomalla, 2011). While disasters comprise a wide range of events, the focus of this paper is on natural disasters, especially those related to hydro-meteorological hazards ${ }^{1}$. These constitute the most widespread type of natural disaster: of the 373 recorded disasters in 2010, 344 (92.2 \%) were of a hydro-meteorological nature (Ferris \& Petz, 2011). Since many tourist destinations are located in coastal areas, tsunamis are of interest as well in this research. For the purpose of this paper a disaster is defined as "a serious disruption of the functioning of a community or a society causing widespread human, material, economic or environmental losses which exceed the ability of the affected community or society to cope using its own resources" (United Nations International Strategy for Risk Reduction, 2009, p.13).

The management of disasters has shifted from a reactive, top-down approach to a more inclusive approach that seeks to proactively reduce the risk of disasters occurring and to minimise the negative consequences for human lives and economic activities (Innocenti \& Albrito, 2011; Thomalla, Downing, Spanger-Siegried, Han \& Rockstroem, 2006). The new paradigm of DRR has been formalised in the internationally widely recognised Hyogo

\footnotetext{
${ }^{1}$ Hydro-meteorological hazards include storms (tropical, thunder and hail), tornados, blizzards, avalanches, coastal storm surges, floods, drought, heatwaves and cold spells, and they can also play a role in other hazards such as landslides or wildfires.
} 
54 Framework for Action (2005-2015) (HFA). The HFA acknowledges the important role of

55 Government agencies, but also explicitly identifies the need to include civil society and other organisations (e.g. trade unions or religious institutions) in disaster management activities. Hence, actions by players that are not formally part of emergency management are no longer considered as disruptive, but are embraced as important additions to the risk management network (e.g. McGee, 2011). The opportunity to capitalise on local or indigenous knowledge and to tap into existing social relationships has been identified as an effective approach to strengthen the resilience of communities in the face of disaster (Larsen et al., 2011).

The tourism sector constitutes an important part of many economies and societies, and should therefore be actively involved in DRR for a number or reasons. Foremost, tourism is about people. Tourists are potentially particularly vulnerable to natural disasters, because they are mobile, difficult to account for and not easy to reach with relevant information (e.g. warnings) (Bird, Gisladottir \& Dominey-Howes, 2010). Often, tourists travel in environments unfamiliar to them, their connectedness with the local communities is very small, they may face language barriers, they are potentially confused about traffic rules, and their predisposition towards positive holiday experiences might obstruct their capacity to absorb information related to natural hazards (Jeuring \& Becken, 2011; WTO, 1998). Furthermore, tourism is a major user of local infrastructure, for example airports, roads, and sewage systems.

Disruptions to these services can have negative repercussions for tourism, both short and long-term, including due to an eroding destination image (e.g. Huan, Beaman \& Shelby, 2004). Tourism businesses represent a very broad spectrum of small, to medium or large enterprises, across very different sectors (e.g. hotels, bus operators, museums). In many places, tourism businesses consider themselves as core members of the local community (Cioccio \& Michael, 2007), and they may also play an important role in providing expertise and equipment in the case of an emergency. However, it is the small businesses that are also 
likely to be most vulnerable to disasters, as they lack the resources and know-how to prepare for impacts (Cioccio \& Michael, 2007; Wang \& Ritchie, 2012).

This paper builds on two premises. One, there is an existing (and largely functioning) international and national system for disaster management that is primarily responsible for reducing risks as well as dealing with actual disasters. The name of these national systems depends on the country, for example Civil Defence and Emergency Management in New Zealand, Emergency Management in Australia, Homeland Security in the United States, Public Safety in Canada, and Katastrophenvorsorge in Germany. Second, tourism is both vulnerable to natural disasters and will benefit from a systematic and strategic approach to disaster management (Ritchie, 2008). The aim of this paper therefore, is to empirically assess how disaster management and tourism work together and whether there is a need or opportunity for tourism to link more formally into existing DRR systems. Based on information from both tourism and emergency management stakeholders a template for achieving such integration is proposed and tested for the case of Northland, New Zealand. New Zealand offers an interesting case study, as it is situated on the border of the AustralPacific tectonic plates and at the convergence of sub-Antarctic and sub-tropical weather patterns. As such it has always been prone to natural disasters, most typically in the form of volcanic eruptions, earthquakes and extreme weather events. To prepare for and respond to disasters, the country invests into an extensive Civil Defence network, headed by the Ministry of Civil Defence Emergency Management (MCDEM) and legislated through the Civil Defence Emergency Management Act 2002. Since DRR follows common principles around the world, the insights from this case study are likely to be relevant for other tourist destinations.

\section{Background}


103 Despite the vulnerability of tourism to natural disasters, the tourism industry tends to be

104 poorly prepared for disasters (Prideaux et al., 2003) taking an almost fatalistic or at best

105 passive approach (Cioccio \& Michael, 2007). In a study on the long term impacts of a major

106 forest fire in Canada, for example, only $28 \%$ of tourism businesses had implemented recovery

107 initiatives 3 years after a major event (Hystad \& Keller, 2008). Similarly, Bird et al. (2010)

108 found that stakeholders in a tourist destination within the hazard zone of the active volcano

109 Katla, Iceland, knew little about emergency management procedures and early warning

110 systems. They also feared that providing related information to tourists would undermine their

111 tourism industry. However, a tourist survey showed that while tourists had little hazard

112 knowledge, they were open to receiving more information on the volcano and on a potential

113 glacial outburst flood (ibid). Tourists, as well as local stakeholders, were also found to be

114 insufficiently informed about tsunami warning systems in the State of Washington (Johnston

115 et al., 2007). Some of the established reasons for these gaps in awareness and implementation

116 include "negative attitudes towards crisis planning, a perceived lack of responsibility for

117 dealing with crises, lack of money, lack of knowledge, lower risk perception, small size of

118 organisations and perceived lack of cohesiveness due to firms being privately owned" (Wang

$119 \&$ Ritchie, 2012, p. 3).

120 Recognising the importance of disaster management for tourism, a number of disaster or crisis

121 management frameworks have been developed for tourism (e.g. Hystad \& Keller, 2008). The

122 most commonly cited framework has been proposed by Faulkner (2001). Faulkner's six

123 phases of disaster management can be comfortably aligned with other mainstream DRR

124 frameworks (Table 1), although Faulkner explicitly adds a so-called Resolution ${ }^{2}$ phase, which

125 provides a feedback loop for improving management plans. Building on Faulkner, Ritchie

126 (2004) proposed an organisational strategy framework aimed at helping tourist organisations

\footnotetext{
${ }^{2}$ In Civil Defence, this would be referred to as 'debrief'.
} 
and destinations to reduce the negative impacts of crisis or disasters. While useful, the above

128 frameworks are reflective of crisis planning research in tourism management and make little explicit reference to existing DRR systems and the associated hazard and emergency management literature, as for example explored by Rokovada (2005) for the case of Fiji. In a

131 more recent publication, Ritchie (2008) drew attention to this gap and called for a more

132 comprehensive and integrative approach to tourism disaster planning and management, as

133 addressed in this paper.

134 Since tourism organisations and small businesses are notoriously under-resourced, it appears

135 efficient to coordinate any tourism disaster management efforts with those already in place. In

136 New Zealand the CDEM Act specifically "encourages coordination across a wide range of

137 agencies, recognising that emergencies are multi-agency events" (MCDEM, 2002, p. 8). A

138 'cluster approach', involving individuals, businesses, emergency services and government

139 departments, is proposed as a means to overcoming communication problems and lack of

140 coordination (MCDEM, no date). While the tourism sector is not mentioned as one of the 12

141 listed clusters, MCDEM notes that new clusters may emerge over time. The underlying

142 framework, the "Four Rs" of Reduction, Readiness, Response and Recovery (Table 1), are

143 effectively implemented in a bottom-up approach, through the establishment of local CDEM

144 groups and Regional Plans developed by the 16 Regional Government bodies in New

145 Zealand. The jurisdictions of these plans align generally well (not in all cases, and some

146 regions have more than one tourism organisation) with the boundaries of Regional Tourism

147 Organisations (RTOs), thereby facilitating (at least theoretically) collaboration. At present,

148 though, the CDEM Group Plans contain little reference to tourism, nor do they include

149 tourism organisations as formal partners in their networks. This shortcoming has also been

150 emphasised by Orchiston (2011) who investigated the implications of a hypothetical

151 earthquake on the Alpine Fault in New Zealand. A number of Group Plans make interesting 
152 observations about tourism and its transient populations (West Coast Plan), which are

153 characterised by different needs, cultures, and languages (Otago Plan). The Canterbury Plan

154 notes that tourists often recreate in remote areas, which pose operational challenges

155 (Marlborough Plan). The Northland Plan refers to the large number of holiday homes as a

156 vulnerability factor.

157 TABLE 1 about here

\section{3. Methods}

159 This research involved several steps using mixed methods. First, empirical data were

160 collected via stakeholder interviews and a survey of tourism operators. The findings from

161 these two data sets formed the basis for populating a template that links tourism into DRR

162 activities and systems. This template was then operationalised via in-depth meetings with key

163 stakeholders and decision makers from both Civil Defence and the tourism sector. It was also

164 agreed upon as the governance structure for a Tourism Action Plan.

165 Northland constitutes a suitable case study for three reasons. One, it is a well-established

166 tourist destination (over 800,000 international visits and about 4.6 million domestic visits per

167 year (Tourism Strategy Group, 2011)). Second, the tourism product is based around the

168 potentially vulnerable coastal and marine activities, alongside cultural and heritage

169 attractions. Third, Northland faces a number of natural hazards (Beetham et al., 2004),

170 including extreme weather (Gray, 2003). Weather hazards typically relate to the occurrence of

171 extra-tropical cyclones (on average one a year) and associated effects such as high winds and

172 heavy rain. Northland's topography of steep central hills and flat terrain means that intense

173 orographic rain and slow draining river systems lead to frequent flooding. The occurrence of

174 extreme climate events will be exacerbated by climate change (Ministry for the Environment, 
175 2008). Further, Northland has experienced four tsunami warnings in the last two years, namely in 2009 (Samoa), 2010 (Chile), 2011 (Japan), and 2011 (Kermadec Trench).

\subsection{Interviews in Northland, New Zealand}

178 To best elicit how both tourism and Civil Defence stakeholders perceive tourism's

179 relationship to DRR, it was decided that qualitative interviews would generate the greatest

180 insights. Interviews offer the opportunity to explore each interviewee's point of view in more

181 depth, allowing for different emphases, perspectives, and personal stories. Importantly,

182 interviews also reveal different values that respondents might have and that are likely to form

183 an important part in their response to any environmental hazard (Morris-Oswald \& Sinclair,

184 2005). The selection of interviewees required considerable thought as it was important to, a)

185 cover a broad range of views and backgrounds and b), involve those in the research process

186 who might become instrumental in the final governance structure of DRR and tourism. Thus,

187 from a Civil Defence perspective, two representatives from the Northland Regional Council

188 (NRC) were interviewed, as well as staff from the Far North district Council, the District

189 Health Board, the Kerikeri Fire Service, Highways North, and the New Zealand Transport

190 Agency (two people). In addition, a selection of tourism stakeholders was interviewed: two

191 hotel managers, two 'i-Site' managers (out of a Northland network of four tourist information

192 centres in Kaitaia, Hokianga, Paihia and Whangarei) and one frontline staff member, the

193 Development Manager (responsible for tourism amongst others) of one of the district

194 councils, and the Chief Executive of Destination Northland, the relevant RTO. Finally, it was

195 important to interview a representative from the Department of Conservation (DoC). DoC is

196 responsible for a network of walking tracks around the region, a forest camp and historic and

197 coastal sites, including a large coastal camping ground holding 450 people at its peak.

198 An interview guide informed the semi-structured interviews. It started by asking interviewees to clarify their specific role in either Civil Defence or tourism. The schedule then covered 
three broad areas: i) links of the individual or their organisation to the Northland CDEM plan

201 or activities, ii) personal views on the tourism sector and associated risk management (e.g.

202 vulnerabilities), and iii) experience of cyclone Wilma (28 January 2011) and recent tsunami

203 warnings. While the interviews focused on the specific situation and expertise of the

204 respondent, a broader perspective (e.g. how other businesses or stakeholders deal with a

205 particular issue) was sought as well, where possible. The interviewers (the two authors)

206 ensured that there was ample flexibility for the respondent to reply and add insights that were

207 not specifically asked for. In some cases, respondents even asked questions, making the

208 interview process reciprocal and sometimes conversational (Cioccio \& Michael, 2007). This

209 was considered important as the interviewees were also seen as key stakeholders for the future

210 implementation of the Tourism Action Plan developed in this research.

211 The twelve interviews involved 16 respondents, lasting between 30 and 90 minutes, and took

212 place in March 2011. All interviews, except one (of which detailed notes were taken), were

213 tape recorded and written up for further analysis. Data were coded according to the Four Rs

214 and relevant sub-themes, gaps and opportunities for improving DRR and tourism were

215 identified. Interview data were also analysed for possible contradictions, conflicts or gaps.

\section{$216 \quad 2.2$ Tourism operator survey}

217 An online questionnaire (using Caltrix) was emailed with a cover letter to 522 members of the

218 Destination Northland database. The survey covered general concerns about disasters and 219 preparedness, knowledge of CDEM activities and plans in Northland, and suggestions for 220 how tourism could or should link into DRR in Northland. The response to the survey was 221 extremely low with 44 questionnaires completed online (response rate of 5\%). According to 222 the Chief Executive of Destination Northland, this is similar to response rates in previous 223 surveys. The answers of the 44 businesses demonstrated relative high awareness, indicating a respondent bias towards those with an interest or even involvement in DRR. Hence, a detailed 
analysis of the full questionnaire seems inappropriate; however, the open ended question

"Please tell us what you think the most important components of the Northland CDEM should be from a tourism business perspective" provides very useful insights and triangulation with the stakeholder interviews, especially given that respondents provided commentary that could comfortably be categorised across all Four Rs. The results from this particular question will therefore be used in this paper.

\subsection{Developing and populating a DRR template for tourism}

232 Building on the empirical results, a template for linking tourism with existing DRR activities 233 was developed and populated using the empirical results. This template explicitly incorporates 234 the current and formal management structure of the Northland CDEM group (NRC, 2010, p. 235 63). In partnership with the Chief Executive of Destination Northland, the template and other emerging issues were then discussed in detail with the Northland Civil Defence Group Manager ( $6^{\text {th }}$ of October, 2011), and the two Civil Defence Controllers from the Far North District Council ( $7^{\text {th }}$ of October). Such a collective approach was seen as essential for the goal of 'linking' tourism into the Civil Defence system. Feedback was collected by taking detailed notes. Further, on the $25^{\text {th }}$ of November, the results and template were presented and discussed at the quarterly meeting of the Northland Tourism Development Group, a consortium of $22 \mathrm{key}$ players involved in tourism. Aside from the general discussion, three

243 specific questions were posed at the conclusion of that meeting. First, is the proposed

244 template helpful and manageable (including consideration of any other potentially preferred 245 approaches); second, should it be developed further; and finally, if yes to the first two 246 questions then when, how and who should be involved in this further development. Again, 247 notes were taken and feedback was discussed verbally between the two researchers. The 248 Northland Tourism Development Group adopted the Tourism Action Plan at their 6 March 2492012 meeting. 


\section{Results}

251

252

253

254

255

256

257

258

259

260

261

262

263

\subsection{Interview and survey findings}

Interview results are structured according to the Four Rs, whereby results are presented in order of tourism stakeholder response, 'government' or CDEM view, and input provided by tourism businesses through the operator survey.

\section{$\underline{\text { Reduction and Readiness in the tourism sector }}$}

In terms of hazard awareness, both tourism and Civil Defence interviewees believed that awareness is generally high amongst tourism businesses, especially since the Boxing Day tsunami in 2004, the Northland floods in 2007, and several recent tsunami warnings. This does not necessarily lead to higher preparedness and a few interviewees noted that many tourism businesses might be underprepared to deal with natural hazards. Some operators appeared to be well prepared (e.g. clearing gutters, evacuating guests): "We knew it (cyclone Wilma) was coming and we had prepared night staff” (Hotel Manager).

Generally, both tourism and Civil Defence stakeholders agreed that tourism is not well integrated with the CDEM system. The lack of specific consideration of tourism (as opposed to agriculture, for example, which is linked into CDEM via a 'rural cluster') is also evidenced in the Northland CDEM Plan (NRC, 2010). Responses from the survey also indicate that a more inclusive and participatory approach that specifically involves tourism would be important (Table 2). Despite this gap, one Civil Defence interviewee pointed out that tourism businesses still fall under the Councils' general land use planning activities and flood mitigation. In practice, it appeared that some accommodation businesses that operated in hazardous areas had difficulties in communicating with the council to achieve mitigating measures. For example, one hotel manager noted that her hotel is "explicitly identified in the 
273 Flood Priority report, but yet no one has me on the radar, or does not seem to want to know

274 about me".

275 The interviews with Civil Defence representatives highlighted that their awareness of tourism

276 or tourists was quite low; although they all expressed interest in working with the tourism

277 sector. The District Health Board was an exception. They showed great concerns about

278 tourists' health and safety, for example: "We are also concerned about tourists getting

279 diseases, i.e. like a pandemic. We are doing the finances about this now, make sure they don't

280 cost too much...there are only 3 GPs (General Practitioners) in the Bay of Islands". The

281 interviews further revealed that there are no formal arrangements for the inclusion of tourism

282 into early warning systems; instead tourism is linked into existing warning systems on an ad

283 hoc case-by-case basis, for example via the i-Site or the national provider of weather

284 information, the MetService. Providing early warning systems alongside clear information on

285 evacuation processes was also highlighted by operators in the survey (Table 2). For tourism to

286 be included in warning networks one of the CDEM interviewees proposed to have, a) one

287 clear contact for tourism and, b) a tourism internal network that passes on the information.

288 Using sirens as part of the warning systems was controversial with both the fire service and

289 Civil Defence interviewees commenting that these might confuse or frighten tourists without

290 providing clear instructions for what to do when the siren can be heard.

291 The risk of over-estimating up-coming disasters was brought up by several interviewees. The

292 difficult balance between warning communities and businesses and creating false alarms

293 (“...for every 7 warnings there will be one that comes to something more serious", Transport

294 Stakeholder) is amplified in the tourism sector that depends on positive messaging for visitors

295 to travel to the area. A Council representative commented that tourism stakeholders "are a bit

296 difficult, they don't know where they belong, before holiday weekends they don't want us to

297 warn and spread bad news, and if it (the disaster) does not materialize we are told off'. 
According to tourism interviewees, based on the experience from Cyclone Wilma there are gaps within the CDEM system itself. For example, interviewees reported that the local and regional councils' 0800 numbers did not provide clear information ahead of an event. One hotel manager reported that following the Japan Tsunami in March 2011 "there were very unclear messages from Civil Defence, and in the end we decided that it would not come to much". Another tourism representative commented in relation to cyclone Wilma on the "dysfunctional system" and that "the Regional Council really need to lift their game".

$\underline{\text { Response to disasters for and by the tourism sector }}$

Tourists constitute a significant addition to the local population of 150,000 residents. The

Chief Executive of Destination Northland was acutely aware that during the peak season in

308 December to February, there could be over 10,000 additional people in the Bay of Islands (a 309 popular tourist place in Northland) alone on an average night. He and others pointed to the 310 inherent risks associated with tourists travelling around the region with no connection to 311 warning systems or other social networks, in particular freedom campers in campervans.

312 Specific operational challenges associated with tourists during an emergency related to 313 evacuating tourists, rescue missions, communication during the event, and road conditions 314 (similarly reflected in the priorities evident from the operator survey, Table 2). These will be 315 discussed in more detail below.

316 To date, no natural disaster has been large enough to enforce a mass evacuation of 317 communities, including tourists. However, past events led some Northland operators to 318 evacuate parts of their premises to ensure tourist safety. Tourism stakeholders reported that 319 the messages from the councils regarding evacuation were unclear and inconsistent:

320 "Following the Chile earthquake last year I evacuated and put people up in the 800 block 321 building with a coffee stand. I rang CDEM twice, but they were not very helpful. The whole 322 thing made me look like an idiot afterwards as I was evacuating and others did not". While 
the Far North District Council Civil Defence controller noted that there are designated areas

324 for evacuation in the case of a tsunami, tourism stakeholders were not necessarily aware of 325 those (apart from “just going uphill”, i-Site manager). It was recognised by a Civil Defence 326 informant that there might be a need for training on how to effectively evacuate tourists. The 327 same interviewee suggested that more information on tourists might need to be collected at 328 check-in to have a better understanding of who is where in the case of an emergency (e.g. 329 passport numbers). He acknowledged that this may be inconvenient for businesses.

330 An important concern by tourism stakeholders related to the communication of road 331 conditions after an event. While businesses and i-Site staff reported that they check the 332 councils websites, as well as the Automobile Association (AA), it was noted by tourism 333 stakeholders that tourists would more likely rely on the AA (responsible for State Highways) 334 or enquire at an i-Site (i-Site manager: "We put up a weather board if the weather is turning 335 ugly. [...] we do have WeatherTrek (a screen) on the wall here for tourists to see "the 336 forecast"). Tourists' inclination to gravitate towards information centres causes a problem in 337 cases where i-Site staff have no access to the latest information themselves ("Most of the 338 tourists came to the counter; it was absolute chaos", i-Site front desk staff). One 339 accommodation provider prints AA pages for tourists and proactively warns bus drivers of 340 tour companies they work with. It was also mentioned by one of the transport interviewees 341 that popular tourist maps do not adequately reflect the nature of roads, for example major 342 versus minor roads. Currently, maps portray tourism values rather than aspects of road safety, 343 and better tourist maps with information on potential flooding spots and other hazards could 344 reduce overall risks. One of the transport interviewees suggested a "starter packet" for tourists 345 to be part of their rental car information, which, amongst others, could provide information 346 such as the frequency for radio stations in the case of an emergency. 
347 Rescues are an important part of responding to an event (see also Table 2). According to a

348 Civil Defence representative, there no distinction is made between tourists and non-tourists;

349 however many of the people requiring rescue from their vehicles are non-locals. If an event

350 happens during holiday time or a weekend the numbers travelling and potentially at risk are

351 larger because of tourists in the area. Visitors were also perceived to be less familiar with the

352 local conditions. Rescues are typically done by the Fire Service and Police. DoC can also be

353 involved at this level, amongst others because they have the resources to respond to

354 emergencies, including staff, 4WD vehicles and a solar-battery radio network. According to

355 the Fire Service, tourism operators may not understand that many of the Civil Defence

356 services are actually based on volunteer networks. Expectations are therefore unrealistically

357 high. In turn, the CEO of Destination Northland reported that in the past some tourist

358 operators, especially those with aircraft or vessels, have become part of the rescue efforts,

359 hence contributing significantly to CDEM.

\section{$360 \quad \underline{\text { Recovery }}$}

361 As identified by tourism operators (Table 2), recovery involves cleaning up, rebuilding

362 infrastructure, and providing business assistance. Communications and engagement with the

363 media is critical. Even localised events or those that result in casualties can have severe

364 repercussions for the destination and its image. As stressed by the CEO of Destination

365 Northland, communication needs to be carefully managed to this effect. The NRC has its own

366 media team and they tend to 'bundle' information from various groups (e.g. police) when they

367 interact with media. The NRC interviewees suggested that there is a potential for tourism to

368 link in with those services and networks. However, it was also noted by tourism interviewees

369 that some media requests are specifically directed at tourism (specifically the CEO of

370 Destination Northland) and this can sometimes happen during or straight after an event. In 
addition, longer term recovery marketing strategies specifically for tourism might be necessary.

373 The issue of insurance was mentioned in one case, where a property was no longer able to

374 secure insurance against flooding. It is unknown to what extent this is a wider problem in the

375 New Zealand tourism sector, for example as reported for businesses in Victoria, Australia

376 (Cioccio \& Michael, 2007). A number of interviewees believed that it is unlikely that many

377 tourism businesses have a formalised business continuation plan. Insurance was not

378 mentioned by operators in the survey.

\subsection{Developing a template for tourism DRR}

380 As evident from the analysis of the empirical data, the Four Rs of the New Zealand CDEM

381 framework are equally applicable to tourism. Thus, linking tourism with the existing

382 framework does not pose any inherent challenges, and avoids a costly reinvention of existing

383 structures. The challenge therefore is not to develop a new DRR system for tourism, but to

384 link tourism and its specific requirements into the existing system. Figure 1 therefore shows a

385 template for linking Northland tourism into the Northland Regional Council CDEM Plan,

386 including the Northland-specific Community Response Plans that are designed to assist self-

387 preparedness of local communities. The arrows in Figure 1 point in both directions to

388 acknowledge that flows of information and resources are mutually beneficial for tourism and

389 Civil Defence players.

390 Despite the principle of aiming to minimize the initiatives and resources required from the

391 tourism sector, strong leadership and commitment are required to effectively and credibly link

392 into DRR activities (Faulkner, 2001). Hystad \& Keller (2008) suggest that destination-based

393 tourism organizations would be the logical lead agencies. The implementation of the template

394 confirmed that Destination Northland should act as the lead agency of a 'tourism cluster' (as

395 suggested in the national legislation), with particular input from the Tourism Development 
Group. Thus, Destination Northland would constitute a single link into the operationally oriented Coordinating Executive Group within the CDEM Plan. Civil Defence staff confirmed that this link would be both appropriate and desirable. Local-level links between tourism and the various Community Response Groups are also important, especially for disaster response and early recovery, and Civil Defence staff commented that any community groups

401 established from here on would ensure tourism is represented. Four Rs by explicitly building on the existing activities with the goal of filling the gaps identified in this and other research. Importantly, the TAP is not a legal document and does not replace any formal Civil Defence jurisdiction. It is rather, in the true sense of the word, a guideline for the tourism destination and its stakeholders to implement specific measures that address their vulnerability to disasters. All Civil Defence staff from the testing phase were supportive of such an approach and offered assistance. Members of the Tourism Development

409 Group supported the proposed template and finalised their first TAP at a meeting in March 2012. The plan is dynamic and requires annual revision and amendments (Table 3). It is also short and focuses on the essential and achievable measures across all Four Rs. For example,

412 an important risk Reduction measure relates to identifying key hazards and ensuring that 413 tourism operators' needs are dealt with adequately in local planning. An important Readiness 414 measure for tourism in Northland is the establishment of a tourism specific communication 415 system for the purpose of early warnings but also other aspects of communication, for 416 example in the phase of recovery. Increasing the ability of core tourism organisations to 417 respond to disasters, including the performance of emergency drills, is a pertinent Response 418 measure. Finally, a repertoire of media release templates to respond swiftly during and after 419 an event was seen as useful to enhance Recovery. 


\section{Discussion}

421 Two main findings have emerged from this research. First, there is a lack of any formal 422 consideration of tourism in Northland's DRR and little collaboration between the tourism 423 sector and emergency organisations. This is consistent with findings of Hystad and Keller 424 (2008), and also implicit in other national and international research that indicates tourism's 425 ill-preparedness for natural disasters (Bird et al., 2010; Hystad \& Keller, 2008; Johnston et al., 426 2007; Orchiston, 2010, 2011). In the New Zealand context this finding is surprising, given 427 that tourism is New Zealand's largest single export earner, and New Zealand is exposed to 428 multiple natural hazards that put key components of the sector at risk. In the absence of 429 collaboration between tourism and disaster management authorities, but a demonstrable need, 430 we proposed a template for connecting Northland tourism and DRR, built around the Four Rs 431 and a Tourism Action Plan. Thus, the second finding is a proposed template that is consistent 432 with earlier frameworks (e.g. Faulkner, 2001) and with the need to integrate disaster management and community planning (Pearce, 2003), articulated in the Hyogo Framework of

434 Action. Linking of tourism and DRR requires efforts from both the tourism sector and Civil 435 Defence organisations.

436 While the integrated template has been developed within a New Zealand, and more 437 specifically Northland region case study context, further development of each of the Four R 438 components can be informed by lessons elsewhere, and not just from the tourism sector. In 439 terms of Reduction, a shift in DRR towards better understanding of underlying causes of 440 vulnerability to certain hazards (and their communication, Kuhlicke et al., 2011), and also a 441 more strategic approach to anticipating future risks (Thomalla et al., 2006) is increasingly 442 being called for (Ritchie, 2008). This includes a need to consider vulnerable groups, such as 443 tourists (e.g. 'freedom campers' identified in this research), but also provides the opportunity 444 to draw on new resources and 'community groups' who assist with DRR (Nivolianitou \& 
445 Synodinou, 2011; McGee, 2011). While the tourism stakeholders, including the Tourism

446 Development Group, consulted in this research demonstrated their willingness to become

447 involved in DRR, the low response rate to the tourist operator survey is concerning. Thus,

448 increasing the involvement of tourism stakeholders in DRR might benefit from research into

449 people's motivations, risk perceptions and other relevant socio-psychological concepts as

450 studied by Martin et al. (2009) in the case of wildfires in high risk communities. Risk

451 education to build capacity (Kuhlicke et al., 2011) may need to become a key element of

452 implementing DRR in tourism.

453 Also relevant to risk reduction is the question whether or not tourist destinations are more

454 vulnerable than other areas (Bird et al., 2010; Meheux \& Parker, 2006; Faulkner, 2001). Tools

455 for risk assessment and reduction are being developed for tourism purposes, e.g., the rapid

456 assessment model suggested by Tsai and Chen (2011) and tested for a hotel in Taiwan.

457 Tourism-specific hazard and vulnerability analyses (e.g. Orchiston, 2011), as well as analyses

458 of subjective risk perceptions, would inform promotion of risk mitigation behaviour,

459 including risk transfer through insurance cover. For example, Treby et al. (2006) reported on

460 how insurers were including hazard perceptions in their risk management models, and

461 emphasised the importance of this information in contexts where development was occurring

462 in more risk prone areas, similar to the Northland flood and tsunami prone areas reported in

463 this study. They promoted the importance of insurance working in a complementary way, and

464 even as an incentive, to mitigation actions. Irrespective of these initiatives the major problem

465 for risk reduction is the inability to think long term and a perception that disasters are out of

466 people's control (Ritchie, 2004).

467 The literature is informative on a range of key components for Readiness, complementary to

468 those identified in this research. Mechanisms include: dedicated tourism disaster

469 spokespeople, annual stakeholder workshops and dedicated webpages (Hystad \& Keller 
2008), holding disaster drills (Bird et al., 2010), and continually updating material

(Quarantelli, 1984, in Faulkner, 2001). In a study on emergency management in Greece,

Nivolianitou and Synodinou (2011) found that common certified training (and as a consequence the use of similar language) would enhance collective capacity of emergency organisations and others involved, for example volunteer groups. These volunteer groups are often not effectively coordinated (as for example found for the 'informal' link of i-Sites with Civil Defence organisations in Northland), but could offer a lot of additional capacity if properly deployed, including knowledge of the local terrain and environment.

The Response phase is the one most commonly observed in DRR, evidenced also in the Community Response Plans developed in Northland. Integrating tourism more explicitly into these local initiatives will strengthen resilience through building local capacity (McGee, 2011). Building social capacity, both in an interventionist and participatory approach, has been recognised as a critical component of successful DRR (Kuhlicke et al., 2011). The participatory approach in this research ensured that tourism stakeholders' perceptions were considered, and the annual review in the action plan is designed to allow inclusion of changing priorities and tourism specific dynamics. It also provides an opportunity for monitoring the robustness of the template. Strengthened capacity at the local level might also help overcome common problems such as communication failure (particularly evident in the Northland case study), availability of resources, and lack of ownership (Meheux \& Parker, 2006). The importance of media was highlighted in this research and elsewhere (e.g. Scott, Laws \& Prideaux, 2008). Potential media issues are varied, for example, media often amplify the negative consequences of a disaster; they are also often unscientific and lack detail, and they also do not focus on risk reduction and preparedness (Pasquare \& Pozzetti, 2007). Communication with media is therefore important both for emergency and tourism 
organisations. Media portrayal can also influence trust in tourist destinations (Eitzinger \&

495 Wiedemann, 2008), with implications on visitation decisions.

496 Recovery is challenging but little reported in the tourism literature, with the exception of 497 some examples relating to the 2004 Indian Ocean tsunami. Using the example of Sri Lanka, 498 Robinson \& Jarvie (2008) highlight how Government's ambition to speed up recovery 499 conflicted with the need for local consultation of affected communities and small tourism 500 businesses to rebuild the destination they envisaged. Decisions in the aftermath of the tsunami 501 in Sri Lanka also highlight how short term recovery decisions may actually compromise long 502 term resilience to future disaster (Ingram et al., 2006). Speed of recovery of tourism also 503 hinges on effectiveness of marketing (Faulkner, 2001), with a risk that tourism disaster plans over-emphasise marketing at the cost of risk reduction. This research highlighted that communication, both internally and externally, are the key pillar of successfully 'bouncing back' to pre-disaster conditions, although Scott et al. (2008) point to the possibility that a 507 disaster might irreversibly change the 'state' of a tourism system or destination, requiring 508 completely new structures and networks to reinvent itself. The TAP could provide guidelines

510 potential catastrophic changes to the destination. It is possible that the Recovery phase is 511 where the TAP, in the future, has to fill the greatest, tourism-specific gaps. This was also 512 indicated in research by Hystad \& Keller (2008), who found that the role of tourism 513 businesses in disaster management is relatively greatest in the Recovery phase.

514 This research, through the development of a template for linking the tourism sector into an 515 existing DRR framework, contributes to both the tourism and disaster management literature. 516 The idea of strengthening DRR by adding the very resourceful (human resources, equipment 517 and capacity) tourism sector aligns fully with the spirit of the Hyogo Framework for Action 518 and the inclusion of communities for mutually beneficial outcomes. The proposed tourism 
cluster, led by the local RTO as the key agency for coordination, leadership, destination

520 development, provision of visitor services and inter-agency liaison (Bornhorst, Ritchie \&

521 Sheehan, 2010), and the TAP, are fully consistent with MCDEM's cluster approach. For

522 tourism itself, better and formalised cooperation with Civil Defence and DRR activities will

523 be beneficial in ensuring tourist safety, business viability, and as a result destination

524 sustainability.

\section{6. Conclusion}

526 Particular and widespread characteristics of the tourism industry, such as the reliance in many

527 places on outdoor-based activities, accommodation located on or near the water and presence

528 of many free and independent travellers, mean it is likely to disproportionately bear the

529 consequences of many natural disasters. For these reasons there has been a growing global

530 interest in disaster management for tourism. But, to date, this interest has been largely

531 tourism-centric and not well integrated with both the theory and application of natural hazard

532 and emergency management. To address this gap, the research reported here has examined

533 tourism within the wider context of DRR, with a focus on Northland, New Zealand as a

534 regional case study. The findings reveal that tourism is little considered in existing DRR, and

535 evidence from Northland demonstrates a range of problems, which in the case of larger and

536 more widespread disasters may be extremely damaging to the tourism industry. However,

537 both tourism stakeholders and representatives from Civil Defence and Government who

538 participated in this research showed a high willingness to address this gap and link the tourism

539 and DRR systems for mutual benefits.

540 Within the above context we have proposed a template for integration of tourism into the

541 wider field of DRR, including the development of a Tourism Action Plan that addresses all

542 the tourism-specific needs that are not already covered in existing DRR activities. The TAP 
543 explicitly considers tourism needs in terms of the Four Rs, i.e., Reduction, Readiness,

544 Response and Recovery. As such the TAP is more than just a response plan, but could be

545 interpreted as a tourism resilience plan. We have been reminded of several key requirements,

546 however, when suggesting the improved integration of the tourism industry with DRR more

547 generally. First, the integration must be a complement and not an overlap of existing

548 activities. This means that tourism becomes a part of the formal Civil Defence network, rather

549 than developing its own structures. Secondly, the TAP needs to be cost effective for the

550 tourism industry and easy to implement. Finally, the integration need only occur where

551 tourism is a significant industry and where it is clearly exposed to the potential effects of

552 natural disasters.

553

$5547 . \quad$ References

555 APEC International Centre for Sustainable Tourism (AICST) (2006). Tourism Risk

556 Management. An Authoritative Guide to Managing Crises in Tourism. Available at

$557 \quad(12 / 10 / 2010)$ http://www.apec.org

558 Beetham, R.D., McSaveney, M., Dellow, G., Rosenberg, M, Johnston, D. \& Smith, W.

559 (2004). A review of natural hazards information for Northland region. Science Report.

$560 \quad$ GNS: Wellington.

561 Bird, D., Gisladottir, G. \& Dominey-Howes, D. (2010). Volcanic risk and tourism in southern

562 Iceland: Implications for hazard, risk and emergency response education and training.

563 Journal of Volcanology and Geothermal Research, 189, 33-48. 
564 Bornhorst, T., Ritchie, B. \& Sheehan, L. (2010). Determinants of tourism success for DMOs

565

566

567

568

569

570

571

572

573

574

575

576

577

578

579

580

581

582

583

584 \& destinations: An empirical examination of stakeholders' perspectives. Tourism Management, 31, 572-589.

Cioccio, L. \& Michael, E.J. (2007). Hazard or disaster: Tourism management for the inevitable in Northeast Victoria. Tourism Management, 28, 1-11.

Commonwealth of Australia (2007). National Tourism Incident Response Plan. Available at (20/01/2011) http://www.ntirp.gov.au

Eitzinger, C. \& Wiedemann, P.M. (2008). Trust in the Safety of Tourist Destinations: Hard to Gain, Easy to Lose? New Insights on the Asymmetry Principle. Risk Analysis, 28(4), 843-853.

Faulkner, B. (2001). Towards a framework for tourism disaster management. Tourism Management, 22(2), 135-147.

Ferris, E. \& Petz, D. (2011). A Year of Living Dangerously. A Review of Natural Disasters in 2010. April, 2011. London: The Brookings Institution - London School of Economics.

Gray, W. (2003). Overview of weather and coastal hazards in the Northland region. Part I: Weather hazards. NIWA Client Report: WLG 2003-57. NIWA: Wellington.

Huan, T., Beaman, J. \& Shelby, L. (2004). No-escape natural disaster. Mitigating impacts on tourism. Annals of Tourism Research, 31(2), 255-273.

Hystad, P.W. \& Keller, P.C. (2008). Towards a destination tourism disaster management framework: Long-term lessons from a forest fire disaster. Tourism Management, 29, $151-162$. 
Ingram, J., Franco, G., Rumbaitis-del Rio, C. and Khazai, B. (2006). Post-disaster recovery dilemmas: challenges in balancing short-term and long-term needs for vulnerability reduction. Environmental Science and Policy, 9, 607-613.

Innocenti, D. and Albrito, P. (2011). Reducing the risks posed by natural hazards and climate change: the need for a participatory dialogue between the scientific community and policymakers. Environmental Science and Policy, in press.

Jeuring, J. \& Becken, S. (2011). Who is protecting tourists in New Zealand from severe weather hazards? An exploration of the role of Locus of Responsibility in protective behaviour decisions. Advancing the Social Science of Tourism 2011. 28th June - 1st July 2011, University of Surrey, United Kingdom.

Johnston, D., Becker, J., Gregg, C., Houghton, B., Paton, D., Leonard, B. \& Garside, R. (2007). Developing warning and disaster response capacity in the tourism sector in coastal Washington, USA. Disaster Prevention and Management, 16, 210-216.

Kuhlicke, C., Steinfuehrer, A. and 21 others (2011). Perspectives on social capacity building for natural hazards: outlining an emerging field of research and practice in Europe. Editorial. Environmental Science \& Policy, 14(7), 804-814.

Larsen, R.L., Calgaro, E. \& Thomalla, F. (2011). Governing resilience building in Thailand's tourism-dependent coastal communities: Conceptualising stakeholder agency in socialecological systems. Global Environmental Change, 21(2), 481-491.

Martin, W.E, Martin, I.M. \& Kent, B. (2009). The role of risk perceptions in the risk mitigation process: The case of wildfire in high risk communities. Journal of Environmental Management, 91, 489-498. 
607 McGee, T.K. (2011). Public engagement in neighbourhood level wildfire mitigation and

608

609

610

611

612 preparedness: Case studies from Canada, the US and Australia. Journal of Environmental Management, 92, 2524-2532.

Meheux, K. \& Parker, E. (2006). Tourist sector perceptions of natural hazards in Vanuatu and the implications for a small island developing state. Tourism Management, 27, 69-85.

Ministry for the Environment (2008). Climate Change Effects and Impacts Assessment: A Guidance Manual for Local Government in New Zealand. Available at (20/10/2010) http://www.mfe.govt.nz/publications/climate/climate-change-effect-impactsassessments-may08/index.html

Ministry of Civil Defence and Emergency Management (2002). Civil Defence Emergency Management Act 2002. Available at (01/08/2011) http://www.civildefence.govt.nz/memwebsite.nsf/wpg_URL/For-the-CDEM-SectorPublications-Index?OpenDocument\#c

Ministry of Civil Defence and Emergency Management (no date). A Cluster Approach for Civil Defence Emergency Management. Available at (23/08/2011) http://www.civildefence.govt.nz/memwebsite.nsf/wpg_URL/For-the-CDEM-SectorPublications-Index?OpenDocument\#c

Morris-Oswald, T. \& Sinclair, A.J. (2005). Values and floodplain management: Case studies from the Red River Basin, Canada. Environmental Hazards, 6, 9-22.

Nivolianitou, Z. \& Synodinou, B. (2011). Towards emergency management of natural disasters and critical accidents: The Greek Experience. Journal of Environmental Management. In press. 
Northland Regional Council (2010). Northland Civil Defence Emergency Management Plan. March 2010. Whangarei.

Orchiston, C. (2010). Tourism and Seismic Risk: Perceptions, preparedness and resilience in the zone of the Alpine Fault, Southern Alps, New Zealand. A thesis submitted for the degree of Doctor of Philosophy at the University of Otago Dunedin, New Zealand. March 2010.

Orchiston, C. (2011). Seismic risk scenario planning and sustainable tourism management: Christchurch and the Alpine Fault zone, South Island, New Zealand. Journal of Sustainable Tourism, 20(1), 59-79.

Pasquare, F. \& Pozzetti, M. (2007). Geological hazards, disasters and the media: The Italian case study. Quaternary International, 173-174, 166-171.

Pearce, L. (2003). Disaster Management and Community Planning, and Public Participation: How to Achieve Sustainable Hazard Mitigation. Natural Hazards, 28, 211-228.

Prideaux, B., Laws, E. \& Faulkner, B. (2003). Events in Indonesia: Exploring the limits to formal tourism trends forecasting methods in complex crisis situations. Tourism Management, 24, 475-487.

Ritchie, B. (2004). Chaos, crises and disasters: a strategic approach to crisis management in the tourism industry. Tourism Management, 25(6), 669-683.

Ritchie, B. (2008). Tourism Disaster Planning and Management: From Response and Recovery to Reduction and Readiness. Current Issues in Tourism, 11(4), 315-348.

Robinson, L. \& Jarvie, J. (2008). Post-disaster community tourism recovery: the tsunami and Arugam Bay, Sri Lanka. Disasters, 32(4), 631-645. 
651 Rokovada, J. (2005). Working Towards Good Governance For Effective Risk Reduction -

652 Fiji Experience. Thematic Session - National Systems for Disaster Risk Management in

653 the Context of Governance: World Conference on Disaster Reduction, 20/01/2005,

654 Kobe Japan. Available at (16/08/2011) http://www.unisdr.org/2005/wcdr/thematic-

655 sessions/presentations/session1-3/fiji-mr-rokovada.pdf

656 Scott, N., Laws, E. \& Prideaux, B. (2008). Tourism Crises and Marketing Recovery

657 Strategies. Journal of Travel \& Tourism Marketing, 23(2-4), 1-13.

658 Thomalla, F., Downing, T., Spanger-Siegfried, E., Han, G. \& Rockstroem, J. (2006).

659 Reducing hazard vulnerability: towards a common approach between disaster risk

$660 \quad$ reduction and climate adaptation. Disasters, 30(1), 39-48.

661 Tourism Queensland (2007). Regional Tourism Crisis Management Plan Template. A guide

662 to preparing a Regional Tourism Crisis Management Plan. Brisbane.

663 Tourism Queensland (2009). Weather Proof Your Business: Incident Response Kit. Available:

664 http://www.tq.com.au/tqcorp_06/fms/tq_corporate/industrydevelopment/Climate\%20Ch

665 ange\%20update\%20v2/Weatherproof\%20Your\%20Business\%20Workbook\%202010.p

$666 \quad \mathrm{df}$

667 Tourism Strategy Group (2011). Tourism Research and Data. Available at (23/01/2012)

$668 \quad$ http://www.med.govt.nz/sectors-industries/tourism/tourism-research-data

669 Tourism Victoria (2010). Crisis Essentials. Crisis Management for tourism businesses.

$670 \quad$ Available at (05/12/2010) www.vic.gov.au/crisis

671 Treby, E.J., Clark, M.J. \& Priest, S.J. (2006). Confronting flood risk: Implications for

672 insurance and risk transfer. Journal of Environmental Management, 81, 351-359. 
673 Tsai, C. \& Chen C. (2011). The establishment of a rapid natural disaster risk assessment

674 model for the tourism industry. Tourism Management, 32, 158-171.

675 UNEP \& CAST (2008). Disaster Risk Management for Coastal Tourism Destinations.

676 Responding to Climate Change. A Practical Guide for Decision Makers. UNEP DTIE:

$677 \quad$ Paris. Available at (08/11/2012)

678 http://www.unep.fr/scp/publications/details.asp?id=DTI/1048/PA

679 United Nations International Strategy for Risk Reduction (2009). 2009 UNISDR Terminology

680 on Disaster Risk Reduction. UNISDR: Geneva, Switzerland. Available at (02/09/2011)

681 http://unisdr.org/files/7817_UNISDRTerminologyEnglish.pdf

682 Wang, J. \& Ritchie, B. (2012). Understanding accommodation managers'crisis planning

683 intention: An application of the theory of planned behavior. Tourism Management.

$684 \quad$ Available online (23/01/2010) doi: 10.1016/j.tourman.2011.12.006

685 World Tourism Organisation (1998). Handbook on Natural Disaster Reduction in Tourist

$686 \quad$ Areas. WTO: Madrid.

687

688

689

Table 1

690 Alignment of Emergency Management phases in different frameworks

\begin{tabular}{|c|c|c|}
\hline $\begin{array}{l}\text { Faulkner's Framework } \\
\text { (2001) }\end{array}$ & $\begin{array}{l}\text { International } \\
\text { frameworks: PPRR } \\
\text { (e.g. Hills, 1998 in } \\
\text { Ritchie, 2008) }\end{array}$ & $\begin{array}{l}\text { New Zealand: the Four Rs used in } \\
\text { the CDEM framework }\end{array}$ \\
\hline $\begin{array}{l}\text { 1. Pre-event phase: } \\
\text { contingency plans, scenario } \\
\text { analyses, hazard } \\
\text { assessments. }\end{array}$ & $\begin{array}{l}\text { Prevention / } \\
\text { Mitigation }\end{array}$ & $\begin{array}{l}\text { Reduction: Identifying and } \\
\text { analysing long-term risks to human } \\
\text { life and property from natural or } \\
\text { man-made hazards; taking steps to } \\
\text { eliminate these risks where } \\
\text { practicable and, where not, } \\
\text { reducing the likelihood and the } \\
\text { magnitude of their impact. }\end{array}$ \\
\hline
\end{tabular}




\begin{tabular}{|c|c|c|}
\hline $\begin{array}{l}\text { 2. Prodromal phase: due to } \\
\text { an imminent disaster, early } \\
\text { warning systems are } \\
\text { activated and command } \\
\text { centres are established. }\end{array}$ & Preparedness & $\begin{array}{l}\text { Readiness: Developing operational } \\
\text { systems and capabilities before an } \\
\text { emergency happens. These include } \\
\text { self-help and response programmes } \\
\text { for the general public, as well as } \\
\text { specific programmes for } \\
\text { emergency services, utilities, and } \\
\text { other agencies. }\end{array}$ \\
\hline $\begin{array}{l}\text { 3. Emergency phase: Actions } \\
\text { are necessary to protect } \\
\text { people and property. } \\
\text { 4. Intermediate phase: short } \\
\text { term needs of people/tourists } \\
\text { have to be addressed and } \\
\text { media communication is } \\
\text { critical. }\end{array}$ & Response & $\begin{array}{l}\text { Response: Actions taken } \\
\text { immediately before, during or } \\
\text { directly after an emergency, to save } \\
\text { lives and property, as well as help } \\
\text { communities to recover. }\end{array}$ \\
\hline $\begin{array}{l}\text { 5. Recovery phase: } \\
\text { Rebuilding of infrastructure, } \\
\text { marketing of destination. } \\
\text { 6.Resolution phase: } \\
\text { evaluation and feedback. }\end{array}$ & Recovery & $\begin{array}{l}\text { Recovery: Activities beginning } \\
\text { after initial impact has been } \\
\text { stabilised and extending until the } \\
\text { community's capacity for self-help } \\
\text { has been restored. }\end{array}$ \\
\hline
\end{tabular}

691

692

693

694

695

696

697 Table 2

698 Suggestions for what a Tourism Action Plan for tourism should contain, provided by

699 respondents to the tourism operator survey (the text in italics highlights the original

700 comments, sorted into themes)

\begin{tabular}{|c|c|c|c|c|}
\hline Reduction & Readiness & Response & Recovery & $\begin{array}{l}\text { Not specific to } \\
\text { one of the Rs }\end{array}$ \\
\hline$\underline{\text { Planning and }}$ & Warning & $\underline{\text { Rescue and welfare }}$ & $\underline{\text { Rebuild }}$ & Communication \\
\hline Mitigation & systems & Rescue people; & $\overline{\text { Recovery; }}$ & $\underline{\mathrm{s}}$ \\
\hline Planning; & (Early) & Lives/ safety $(3 x)$; & Resume B A U; & Communication \\
\hline Prevention; & Warning (4x); & Emergency & Fast clean-up & $(6 x)$ \\
\hline Disease & Prediction; & evacuation and & after damage; & Being \\
\hline $\begin{array}{l}\text { prevention; } \\
\text { How would our }\end{array}$ & $\begin{array}{l}\text { Communicatio } \\
n \text { of potential }\end{array}$ & $\begin{array}{l}\text { accommodation; } \\
\text { Food \& shelter }\end{array}$ & $\begin{array}{l}\text { Restore } \\
\text { infrastructure; }\end{array}$ & $\begin{array}{l}\text { informative; } \\
\text { Information }\end{array}$ \\
\hline
\end{tabular}




\begin{tabular}{|c|c|c|c|c|}
\hline $\begin{array}{l}\text { buildings cope } \\
\text { with a tropical } \\
\text { cyclone? } \\
\text { Identify \& } \\
\text { prioritise } \\
\text { emergency } \\
\text { response } \\
\text { Consultation } \\
\text { and education } \\
\text { Inclusive } \\
\text { strategic } \\
\text { planning; } \\
\text { Consultation; } \\
\text { Make all } \\
\text { operators } \\
\text { aware of steps } \\
\text { to take; } \\
\text { Educating and } \\
\text { communicating } \\
\text { the actual } \\
\text { CDEM Plan; } \\
\text { Educating the } \\
\text { tourism industry } \\
\text { with regards to } \\
\text { the natural } \\
\text { dangers within } \\
\text { a specific } \\
\text { location; } \\
\text { Involve tourism } \\
\text { groups. At } \\
\text { Oakura Bay it is } \\
\text { just residential }\end{array}$ & $\begin{array}{l}\text { disaster } \\
\frac{\text { Evacuation }}{\frac{\text { and }}{\text { communicatio }}} \\
\underline{\underline{n}} \text { Clear } \\
\text { communication } \\
\text { before, during } \\
\text { and after to } \\
\text { ensure we } \\
\text { make the best } \\
\text { possible } \\
\text { decisions for } \\
\text { our guests, } \\
\text { crew and } \\
\text { business; } \\
\text { Evacuation } \\
\text { process } \\
\text { communicated } \\
\text { including } \\
\text { location and } \\
\text { warning } \\
\text { signals: } \\
\text { what/how/ } \\
\text { when }\end{array}$ & $\begin{array}{l}(3 x) ; \\
\text { Ensure safety of } \\
\text { people including } \\
\text { tourists; } \\
\text { Support to get } \\
\text { visitors out if } \\
\text { required or into } \\
\text { appropriate } \\
\text { shelter; } \\
\text { Assistance in an } \\
\text { emergency; } \\
\text { Services offered to } \\
\text { tourists after } \\
\text { disasters } \\
\text { Transportation } \\
\text { Clearance of roads } \\
\text { in and out for } \\
\text { supplies and } \\
\text { people; } \\
\text { Traffic } \\
\text { management; } \\
\text { Roading } \\
\text { Communications } \\
\text { Easy to contact } \\
\text { (2x); } \\
\text { Establishing } \\
\text { communications } \\
\text { with cut off areas; } \\
\text { Keeping the press } \\
\text { from } \\
\text { sensationalism } \\
\text { which kills tourism } \\
\text { more than the } \\
\text { disaster } \\
\end{array}$ & $\begin{array}{l}\text { Helping repair } \\
\text { lives and towns } \\
\text { after disaster } \\
\text { Assistance } \\
\text { Economic help } \\
\text { in case of } \\
\text { complete global } \\
\text { economic } \\
\text { breakdown } \\
\text { Communications } \\
\text { Promotional that } \\
\text { all is operating; } \\
\text { Communication } \\
\text { process for } \\
\text { overseas } \\
\text { tourists; } \\
\text { Savvy Media } \\
\text { skills }\end{array}$ & $\begin{array}{l}\text { Hazards } \\
\text { Flooding/ } \\
\text { Storms; } \\
\text { Water; } \\
\text { Tsunami; } \\
\text { Monitoring; } \\
\text { Likelihood of } \\
\text { volcanic } \\
\text { eruption for } \\
\text { each known } \\
\text { volcano, and } \\
\text { possible scale of } \\
\text { it; } \\
\text { Major power } \\
\text { cut } \\
\text { Other } \\
\text { Local civil } \\
\text { defence } \\
\text { organisation; } \\
\text { Keep a high } \\
\text { profile in the } \\
\text { community; } \\
\text { Economics; } \\
\text { Remedy }\end{array}$ \\
\hline
\end{tabular}


704 Tourism Action Plan adopted by the Tourism Cluster in Northland

\begin{tabular}{|c|c|c|c|}
\hline & Action & Leadership & Preparation \\
\hline 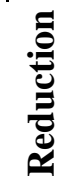 & $\begin{array}{l}\text { Identify, map, } \\
\text { understand hazards } \\
\text { for businesses }\end{array}$ & $\begin{array}{l}\text { Civil Defence in } \\
\text { partnership with } \\
\text { Destination Northland }\end{array}$ & $\begin{array}{l}\text { Use existing hazard assessments (e.g. } \\
\text { tsunami maps) and ensure tourism } \\
\text { operators know about them. }\end{array}$ \\
\hline \multirow{4}{*}{ 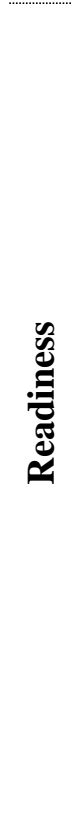 } & $\begin{array}{l}\text { Develop a } \\
\text { Communication } \\
\text { Network }\end{array}$ & $\begin{array}{l}\text { Information centres } \\
\text { coordinate development } \\
\text { of contact tree by sub } \\
\text { region and by industry } \\
\text { group }\end{array}$ & $\begin{array}{l}\text { Identify existing phone contact trees; } \\
\text { Develop trees for gaps (consider new } \\
\text { technology like twitter); } \\
\text { Ensure that trees are linked to CD in } \\
\text { most efficient way; } \\
\text { Discuss back up and data sharing } \\
\text { protocols. }\end{array}$ \\
\hline & $\begin{array}{l}\text { Tourism linked into } \\
\text { CEG }\end{array}$ & Destination Northland & $\begin{array}{l}\text { Attend meetings of the Coordinating } \\
\text { Executive Group in CDEM. }\end{array}$ \\
\hline & Annual Review & $\begin{array}{l}\text { Tourism Development } \\
\text { Group }\end{array}$ & $\begin{array}{l}\text { Allocate slot in meeting once a year to } \\
\text { discuss CDEM; } \\
\text { Use existing checklists (e.g. PATA). }\end{array}$ \\
\hline & $\begin{array}{l}\text { Business Crisis "To- } \\
\text { do" list and plan }\end{array}$ & $\begin{array}{l}\text { Destination Northland } \\
\text { in partnership with } \\
\text { Civil Defence }\end{array}$ & $\begin{array}{l}\text { Workshop format; } \\
\text { Use templates, e.g. Tourism Victoria. }\end{array}$ \\
\hline \multirow{2}{*}{ 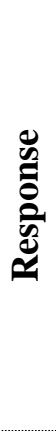 } & $\begin{array}{l}\text { Destination } \\
\text { Northland Crisis } \\
\text { Plan }\end{array}$ & Destination Northland & $\begin{array}{l}\text { Hold a staff meeting and collect } \\
\text { information on contact details and what } \\
\text { people would do in an emergency; } \\
\text { Perform emergency drills. }\end{array}$ \\
\hline & I-Site Crisis Plan & $\begin{array}{l}\text { I-Sites, either } \\
\text { individually or } \\
\text { collectively }\end{array}$ & $\begin{array}{l}\text { Hold a staff meeting and collect } \\
\text { information on contact details and what } \\
\text { people would do in an emergency; } \\
\text { Perform emergency drills. }\end{array}$ \\
\hline \multirow{2}{*}{ 离 } & $\begin{array}{l}\text { Ensure tourism is } \\
\text { well connected }\end{array}$ & $\begin{array}{l}\text { Tourism Development } \\
\text { Group }\end{array}$ & $\begin{array}{l}\text { Keep informed and maintain contacts } \\
\text { with important national and regional } \\
\text { organisation that might assist recovery. }\end{array}$ \\
\hline & $\begin{array}{l}\text { External } \\
\text { communications } \\
\text { plan and templates }\end{array}$ & $\begin{array}{l}\text { Destination Northland } \\
\text { and businesses }\end{array}$ & $\begin{array}{l}\text { Prepare templates and keep them in a } \\
\text { readily available folder and } \\
\text { electronically; } \\
\text { Consider media training for emergency. }\end{array}$ \\
\hline
\end{tabular}




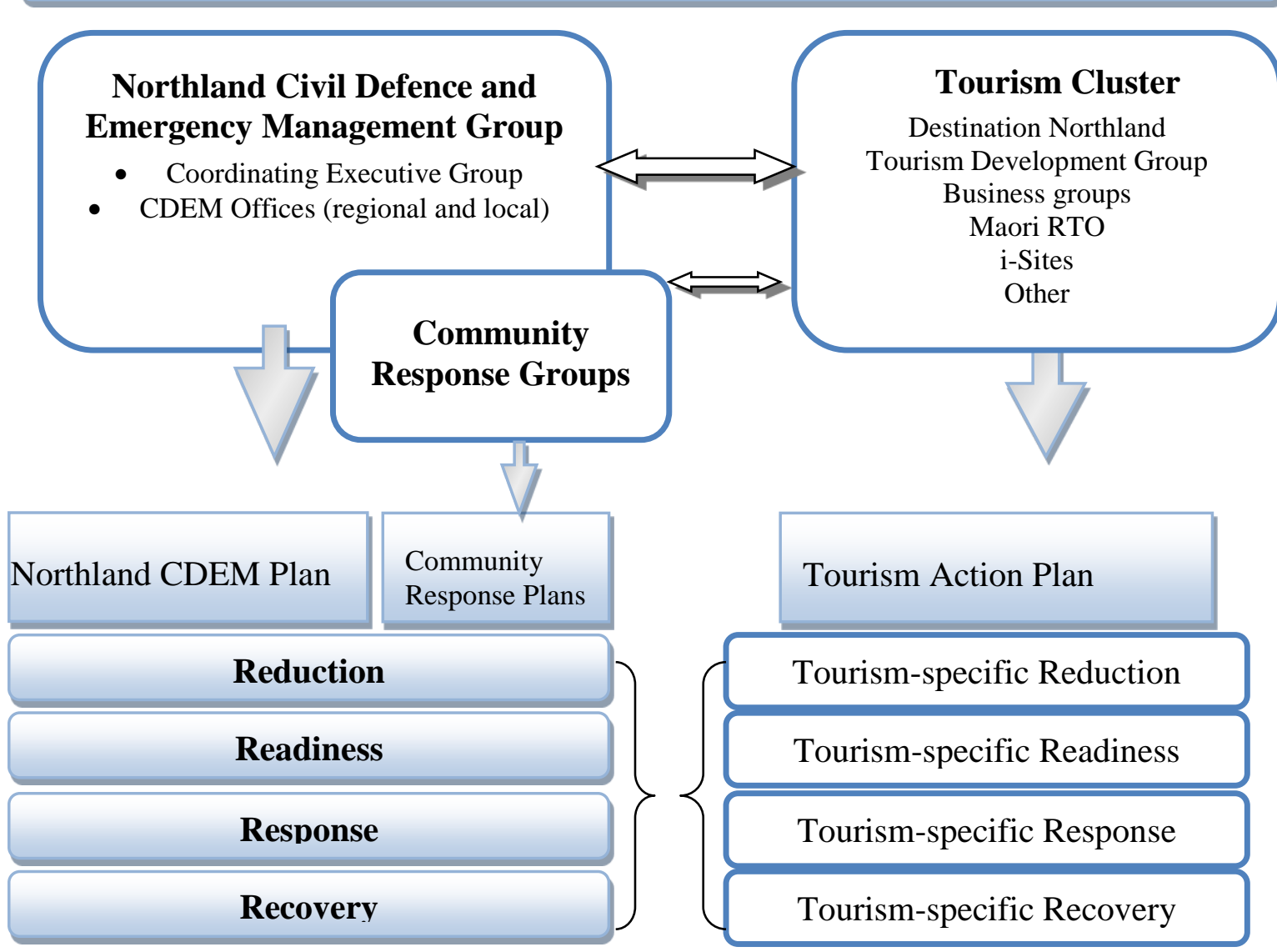

\section{TOURISM}

723

Figure 1

Template for linking tourism into the existing Civil Defence structure (on the left hand side of the Figure) based 